Lentera Pustaka 2 (2): 71-81, 2016

Copyright (C2016, ISSN: 2302-4666 print/ 2540-9638 online

Available Online at: http://ejournal.undip.ac.id/index.php/lpustaka

\title{
STUDI EKSPERIMEN MENGENAI METODE BACA GOOD READING
}

\author{
Prijana $^{1 *)}$, Asep Saeful Rohman ${ }^{2}$ \\ ${ }^{1,2)}$ Program Studi Ilmu Perpustakaan Fakultas Ilmu Komunikasi Universitas Padjadjaran, \\ Jl. Ir. Soekarno KM. 21 Jatinangor Sumedang \\ *)Korespondensi : prijanafikom@gmail.com
}

\begin{abstract}
[Title: Experimental Research About Good Reading Method] This research was conducted in order to determine the correlation read using good reading method and Benchmark Reference Rate (PAP) on students' academic achievement. Student academic achievement using the provisions grade point average (GPA). The method used in this research is quantitative and observation method using experimental studies. Participants in this study were students of Library Science Program Faculty of Communication Padjadjaran University, with the experimental group $(N=34)$ and control group $(N=44)$. The results showed that the academic achievement of students who are classified low, medium, and high, have a significant relationship with a good read method of reading. Academic achievement is classified using PAP (Benchmark Reference Rate), has a significant relationship with good reading method. It can be said that the PAP method is more suitable to classify the students' academic achievement. Good reading method has a higher confidence than the reading habit if it is associated with students' academic achievement.
\end{abstract}

Keywords : Good Reading Method, Reading Habit Method, Text Science, Academic Achievement, Student Reading Ability.

\begin{abstract}
Abstrak
Penelitian ini dilakukan dengan tujuan untuk mengetahui korelasi kegiatan membaca teks ilmu pengetahuan menggunakan metode good reading dan Penilaian Acuan Patokan (PAP) dengan prestasi akademik mahasiswa. Prestasi akademik mahasiswa menggunakan ketentuan indeks prestasi kumulatif (IPK). Metode yang digunakan dalam penelitian ini adalah kuantitatif dan metode observasi menggunakan studi eksperimen. Partisipan dalam penelitian ini adalah mahasiswa Program Studi Ilmu Perpustakaan Fakultas Ilmu Komunikasi Universitas Padjadjaran, dengan kelompok eksperimen $(N=34)$, dan kelompok kontrol $(N=44)$. Hasil penelitian menunjukkan bahwa prestasi akademik mahasiswa yang diklasifikasikan rendah, sedang, dan tinggi, memiliki hubungan significant dengan metode baca good reading. Prestasi akademik yang diklasifikasikan menggunakan metode PAP (Penilaian Acuan Patokan), memiliki hubungan significant dengan metode baca good reading. Dapat dikatakan bahwa metode PAP lebih cocok digunakan untuk mengklasifikasi prestasi akademik mahasiswa. Metode baca good reading memiliki kepercayaan lebih tinggi dibandingkan dengan metode reading habit jika dikaitkan dengan prestasi akademik mahasiswa.
\end{abstract}

Kata Kunci : Metode Baca Good Reading, Metode Baca Reading Habit, Teks Ilmu Pengetahuan, Prestasi Akademik, Kemampuan Baca Mahasiswa

\section{Pendahuluan}

Dalam literatur Ilmu Perpustakaan dan Informasi dikatakan bahwa kegiatan membaca itu merupakan aktivitas artifisial, yakni aktivitas yang dipelajari dan berlangsung terus-menerus. Hasil studi eksperimen, Prijana \& Asep Saeful Rohman (2015) mengatakan bahwa mahasiswa memiliki keterampilan dan keterlatihan membaca yang berbeda satu sama lainnya. Mereka memiliki kecepatan 
waktu baca yang berbeda satu sama lainnya. Mereka yang memiliki prestasi akademik lebih tinggi memiliki kecenderungan lebih cepat waktu bacanya dibandingkan dengan yang memiliki prestasi akademik lebih rendah. Mereka yang memiliki prestasi akademik lebih tinggi, memiliki kebiasaan membaca yang juga berbeda dengan yang memiliki prestasi lebih rendah. Mereka yang memiliki prestasi akademik lebih tinggi, sering melakukan aktivitas membaca dibandingkan dengan yang memiliki prestasi akademik lebih rendah. Disini tingkat keseringan membaca diartikan sebagai keterlatihan. Sehingga dapat dikatakan bahwa semakin terlatih membaca, semakin cepat waktu bacanya.

Gagasan mengenai membaca (reading) yang dikemukakan Mortimer J. A. \& Charles, V. D. (1940an) dalam bukunya yang berjudul How to Read a Bookpernah menggemparkan Eropa. Mereka memandang bahwa gagasan dalam buku tersebut mengantarkan masyarakat Eropa menjadi literate. Pada tahun 1972 buku How to Read a Bookdicetak kembali dalam edisi Amerika, dan juga berdampak positif pada masyarakat Amerika. Gagasan Adler and Doren ini juga menginspirasi para cendekiawan Amerika, diantaranya Frank Hatt (1976) dalam bukunya The Reading Process yang secara eksplisit mencoba memahami apa itu membaca, who is the reader ? Frank Hatt (1976) mencoba untuk memahami dan mengatakan bahwa This reader, in existential reading situation, is a person who is literate, yang selanjutnya ia tegaskan lagi bahwa The reader is a literate person.

Dibalik gagasan besar Adler \& Doren (1940-an) tersebut, masih ditemukan pandangan-pandangan yang selama ini belum terungkap secara lebih terang. Dalam edisi Amerika (1972) ia menegaskan bahwa reading is tools. Gagasan inilah yang menginspirasi Moyle (1973) untuk menciptakan formula mengenai dimensi baca (reading) yakni good reading. Sehingga semakin jelas bahwa membaca itu memerlukan skill dan tatacara membaca. Gagasan Moyle inilah yang mengantarkan idea untuk melakukan studi eksperimen mengenai dimensi baca. Ia mengatakan bahwa baca buku teks yang benar itu diawali rasa senang (enjoy read) sebelum melakukan aktivitas membaca. Kemudian langkah pertama, yakni melakukan membaca dengan cara cepat (read faster), kemudian membaca kembali (read more), dan membaca sekali lagi untuk maksud memahami teks (understanding better).

Prijana (2016) dalam studi eksperimennya yang berjudul: Hubungan membaca teks illmu pengetahuan melalui metode good reading dengan nilai prestasi akademik,dengan $(\mathrm{N}=34)$ dan jika $\alpha=$ $0.25 ; \mathrm{df}=2$; maka nilai prestasi akademik mahasiswa memiliki hubungan signifikan dengan kemampuan membaca teks Ilmu pengetahuan melalui metode good reading; jika $\alpha=0.10 ; \mathrm{df}=2$; maka nilai prestasi akademik mahasiswa memiliki hubungan non-signifikan dengan kemampuan baca teks ilmu pengetahuan melalui metode good reading. Prijana (2016a) memahami nilai prestasi akademik dalam konteks menjawab soal secara heterogen, yakni soal multiple-choice, soal jawaban 'benar - salah', dan soal esai, dalam satu kesatuan jawaban. Disini prestasi akademik memiliki hubungan significant dengan metode baca good reading, jika pada derajat kepercayaan $75 \%$.

Prijana \& Sukaesih (2016) dalam studi eksperimennya yang berjudul: Hubungan Kemampuan Baca Mahasiswa Melalui Metode Good Reading Dengan Kemampuan Menjawab Soal Multiple-choice, dengan $(\mathrm{N}=34)$ dan jika $\alpha=0.10 ; \mathrm{df}=4$; maka kemampuan menjawab soal multiplechoice memiliki hubungan 
significant dengan metode baca good reading. Disini kemampuan mahasiswa menjawab soal muitiplechoice memiliki hubungan significant dengan metode baca good reading, jika pada derajat kepercayaan $90 \%$.

Prijana \& Andri Yanto (2016) dalam studi eksperimennya yang berjudul: Uji Korelasi Tentang Prestasi Akademik Dengan Metode Baca Mahasiswa, dengan ( $N=34)$ dan jika $\alpha=0.01$; $\mathrm{df}=32$; maka prestasi akademik mahasiswa memiliki hubungan korelasi significant dengan metode baca good reading. Disini prestasi akademik mahasiswa memiliki hubungan korelasi significant dengan metode baca good reading, jika sampai derajat kepercayaan $99 \%$.

Dalam 3 (tiga) penelitian tampak bahwa analisis dalam studi eksperimen menunjukkan hasil yang berbeda-beda, karena itu peneliti merasa perlu terus melakukan pengujian-pengujian statistik dengan beberapa rekayasa statistik. Adapun pertanyaan ekspresimen dalam penelitian ini adalah :

a. Kelompok eksperimen :

Apakah prestasi akademik mahasiswa memiliki hubungan significant dengan penggunaan metode baca good reading?

b. Kelompok kontrol :

Apakah prestasi akademik mahasiswa memiliki hubungan significant dengan penggunaan metode baca reading habit?

\section{Metode Penelitian}

Metode penelitian yang digunakan adalah penelitian kuantitatif, yakni positivis modern atau post positivis. Metode post positivis bersifat kausalitatif, yakni hubungan sebab-akibat, tunduk pada ruang dan waktu. Metode post positivis berbasiskan data (sense datum) dan metode verifikasi, yakni uji hipotesis. Sementara metode observasinya adalah eksperimen.

Metode observasi yang digunakan adalah eksperimen. Krathwohl (1993) mengatakan bahwa metode eksperimen merupakan metode untuk menguji hipotesis, yakni menguji keterkaitan variabel bebas (independent variable) dan variabel terikat (dependent variable). Variabel bebas adalah variabel rekayasa. Sementara variabel terikat adalah konstan. Hasil rekayasa variabel bebas terhadap variabel terikat dapat diukur/diuji (measurable). Diawal percobaan kedua kelompok diasumsikan sama. Perbedaan yang terjadi disebabkan oleh perlakuan yang diberikan pada kelompok eksperimen.

Good dalam Sevilla (2008), memahami metode eksperimen ssebagai berikut: paling sedikit dapat dilakukan dalam satu kondisi yang dapat dimanipulasikan. Sementara kondisi yang lain dianggap konstan. Kemudian pengaruh perbedaan kondisi tersebut dapat diuji (measurable). Manipulasi kondisi atau yang dikenal dengan variabelini merupakan karakteristik yang membedakan penelitian eksperimen dengan metode lainnya. Variabel bebas (independent variable) dapat diartikan sebagai variabel eksperimen yang karakteristiknya diyakini dapat menghasilkan perbedaan. Sementara variabel terikat (dependent variable) sebagai variabel standar (Criterion variable) yang merupakan hasil dari penelitian. 
Partisipan adalah mahasiswa Program Studi Ilmu Perpustakaan Fakultas Ilmu Komunikasi Universitas Padjadjaran, dengan kelompok eksperimen ( $\mathrm{N}=34)$, dan kelompok kontrol $(\mathrm{N}=44)$. Kelompok eksperimen menggunakan metode baca good reading dan kelompok kontrol menggunakan metode baca reading habit. Selanjutnya metode analisis yang digunakan adalah statistika sosial. Metode analisis yang digunakan adalah statistik deskriptif, yakni analisis kontingensi Chi-kuadrat (2X3), dan Chi-kuadrat (2X5), dengan skala nominal. Prestasi akademik diklasifikasi menjadi 3 (tiga) klasifikasi, yakni rendah, sedang, dan tinggi, dan diklasifikasi menurut PAP, 5 (lima) klasifikasi. Sementara metode baca diklasifikasi menjadi 2 (dua) klasifikasi, yakni berdasarkan IPK (Indeks Prestasi Kumulatif), Yakni IPK rendah dan IPK tinggi.

\section{Hasil Penelitian Dan Pembahasan : Hubungan Prestasi Akademik Dengan Metode Baca}

Pada bagian ini dipaparkan dan dibahas tentang hasil penelitian tentang bagaimana hubungan prestasi akademik dengan metode baca good reading baik pada mahasiswa yang terdapat pada kelompok eksperimen maupun kelompok kontrol. Pada kelompok eksperimen dengan $\mathrm{N}=34$, hipotesisnya yakni :

$\mathrm{H}_{0}$ : Prestasi akademik memiliki hubungan non-signifikan dengan metode baca Good Reading.

$\mathrm{H}_{1}$ : Prestasi akademik memiliki hubungan signifikan dengan metode baca Good Reading.

Berdasarkan hasil penelitian, maka diperoleh hasil sebagai berikut :

Tabel 1 : Hubungan Prestasi Akademik Mahasiswa dengan Metode Baca Good Reading Berdasarkan Klasifikasi Sturges

\begin{tabular}{|c|c|c|c|c|}
\hline & $\begin{array}{l}\text { Nilai rendah } \\
(15.00-36.00)\end{array}$ & $\begin{array}{c}\text { Nilai sedang } \\
(37.00-58.00)\end{array}$ & $\begin{array}{l}\text { Nilai tinggi } \\
(59.00-80)\end{array}$ & Jumlah \\
\hline $\begin{array}{c}\text { IPK tinggi } \\
(3.46-3.93)\end{array}$ & 3.09 & 12.97 & 4.94 & 21 \\
\hline $\begin{array}{l}\text { IPK rendah } \\
(2.98-3.45)\end{array}$ & 4 & 8.03 & 1 & 13 \\
\hline Jumlah & 5 & 21 & 8 & 34 \\
\hline
\end{tabular}

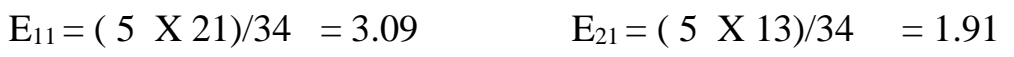

$$
\begin{aligned}
& \mathrm{E}_{12}=(21 \times 21) / 34=12.97 \quad \mathrm{E}_{22}=(21 \times 13) / 34=8.03
\end{aligned}
$$

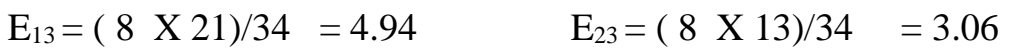

$$
\begin{aligned}
& { }^{2}=\frac{(1-3.09)^{2}}{3.09}+\frac{(13-12.97)^{2}}{12.97}+\frac{(7-4.94)^{2}}{4.94}+\frac{(4-1.91)^{2}}{1.91}+\frac{(8-8.03)^{2}}{8.03} \\
& +(1-3.06)^{2} \\
& 3.06 \\
& =5.95
\end{aligned}
$$


Jika $\alpha=0.10 ; \mathrm{df}=2$, maka Chi-quadrat $($ tabel $)=4.61$; artinya Chi-quadrat (hitung) $=$ 5.95 lebih besar daripada Chi-quadrat (tabel) $=4.61$. Jika Chi-quadrat (hitung) lebih besar daripada Chi-quadrat (tabel), maka prestasi akademik memiliki hubungan significant dengan metode good reading. Sehingga dapat dikatakan bahwa dengan derajat kepercayaan $90 \%$ diketahui, prestasi akademik mahasiswa memiliki hubungan significant dengan metode good reading, artinya hipotesis: diterima. Disini dapat dikatakan bahwa indeks prestasi komulatif (IPK) mahasiswa berkaitan dengan capaian prestasi akademik. Tinggi dan rendahnya IPK diamati dari klasifikasi dan interval nilai IPK kelas dengan menggunakan modifikasi Sturges (literatur statistik). Jika kita cermati berdasarkan banyaknya frekuensi (f) partisipan, mereka yang memiliki IPK tinggi dan rendah kurang lebih (60\%: 40\%), artinya disini mahasiswa dengan IPK tinggi lebih banyak dibandingkan dengan mereka yang IPK rendah. Mereka yang memiliki IPK tinggi memiliki sebaran nilai diantara nilai sedang sampai tinggi. Sementara mereka yang memiliki IPK rendah memiliki sebaran nilai diantara nilai sedang sampai rendah. Disini terdapat capaian prestasi yang relatif sama antara mereka yang memiliki IPK rendah dan tinggi, yakni pada capaian nilai sedang (yakni pada kisaran 61\%), artinya metode baca good reading mampu mengantarkan pada capaian level prestasi akademik yang sama, selebihnya karena faktor lain yang tak dapat disebutkan, namun dapat diperkirakan besarannya $(40 \%)$.

Jika $\alpha=0.05 ; \mathrm{df}=2$, maka Chi-quadrat (tabel) $=5.99$; artinya Chi-quadrat (hitung) = 5.95 lebih kecil daripada Chi-quadrat (tabel) $=5.99$. Jika Chi-quadrat (hitung) lebih kecil daripada Chi-quadrat (tabel), maka prestasi akademik mahasiswa memiliki hubungan nonsignificant dengan metode baca good reading. Kesimpulan: dengan derajat kepercayaan 95\% diketahui bahwa prestasi akademik memiliki hubungan non-signifikan dengan metode baca good reading. Hipotesis : ditolak. Disini derajat kepercayaan turut mempengaruhi signifikansi atau non-signifikansi antara prestasi akademik mahasiswa dengan metode baca good reading. Sehingga dapat dikatakan bahwa signifikansi hubungan terletak pada derajat kepercayaan $90 \%$.

Selanjutnya, jika kita coba lakukan rekayasa konseptual nilai mutu akademik, dengan mengikuti metode PAP (Penilaian Acuan Patokan), maka penilaian pada penguasaan materi kognitif, psikomotorik, dan afeksi sebagai berikut : A $(80$ - 100), B (68 - 79),C (56 - 67), D $(45-55), \mathrm{E}(0-44)$. 
Tabel 2 : Hubungan Prestasi Akademik Mahasiswa dengan Metode Baca Good Reading Berdasarkan Klasifikasi Sturges

\begin{tabular}{|c|c|c|c|c|c|c|}
\hline & $\begin{array}{c}E \\
(0-44)\end{array}$ & $\begin{array}{c}\mathrm{D} \\
(44-55)\end{array}$ & $\begin{array}{c}\mathrm{C} \\
(56-67)\end{array}$ & $\begin{array}{c}\mathrm{B} \\
(68-79)\end{array}$ & $\begin{array}{c}\mathrm{A} \\
(80-100)\end{array}$ & Jumlah \\
\hline $\begin{array}{l}\text { IPK tinggi } \\
(3.46-3.93)\end{array}$ & $\begin{array}{ll}3 & \\
& 6.79\end{array}$ & 9 & 3.70 & 2.47 & 0 & 21 \\
\hline $\begin{array}{l}\text { IPK rendah } \\
(2.98-3.45)\end{array}$ & $\begin{array}{ll}8 & \\
& 4.20\end{array}$ & 4.97 & 2.29 & 1.53 & 0 & 13 \\
\hline Jumlah & 11 & 13 & 6 & 4 & 0 & 34 \\
\hline
\end{tabular}

$$
\begin{aligned}
& \mathrm{E}_{11}=(11 \times 21) / 34=6.79 \\
& \mathrm{E}_{21}=(11 \times 13) / 34=4.20 \\
& E_{12}=(13 \times 21) / 34=8.03 \\
& E_{22}=(13 \times 13) / 34=4.97 \\
& E_{13}=(6 \times 21) / 34=3.70 \\
& \mathrm{E}_{23}=(6 \times 13) / 34=2.29 \\
& \mathrm{E}_{14}=(4 \times 21) / 34=2.47 \\
& \mathrm{E}_{24}=(4 \times 13) / 34=1.53 \\
& \mathrm{E}_{15}=(0 \times 21) / 34=0 \\
& \mathrm{E}_{25}=\left(\begin{array}{l}
0 \times 13) / 34=0 \\
0
\end{array}\right. \\
& \begin{aligned}
2 & =\frac{(3-6.79)^{2}}{6.79}+\frac{(9-8.03)^{2}}{8.03}+\frac{(6-3.70)^{2}}{3.70}+\frac{(3-2.47)^{2}}{2.47}+\frac{(0-0.00)^{2}}{0.00} \\
& +\frac{(8-4.20)^{2}}{4.20}+\frac{(4-4.97)^{2}}{4.97}+\frac{(0-2.29)^{2}}{2.29}+\frac{(1-1.53)^{2}}{1.53}+\frac{(0-0.00)^{2}}{0.00} \\
& =9.85
\end{aligned}
\end{aligned}
$$

Jika $\alpha=0.10 ; \mathrm{df}=4$, maka Chi-quadrat $($ tabel $)=7.78 ;$ artinya Chi-quadrat (hitung) $=9.85$ lebih besar daripada Chi-quadrat (tabel) $=7.78$. Jika Chi-quadrat (hitung) lebih besar daripada Chi-quadrat (tabel), maka prestasi akademik memiliki hubungan significant dengan metode baca good reading. Kesimpulan: dengan derajat kepercayaan 90\% diketahui bahwa prestasi akademik mahasiswa memiliki hubungan significant dengan metode baca good reading. Hipotesis : diterima.

Jika $\alpha=0.05 ; \mathrm{df}=4$, maka Chi-quadrat $($ tabel $)=9.49 ;$ artinya Chi-quadrat (hitung) $=9.85$ lebih besar daripada Chi-quadrat (tabel) $=9.49$. Jika Chi-quadrat (hitung) lebih besar daripada Chi-quadrat (tabel), maka prestasi akademik mahasiswa memiliki hubungan significant dengan metode baca good reading. Kesimpulan: dengan derajat kepercayaan 95\% diketahui bahwa prestasi akademik mahasiswa memiliki hubungan significant dengan metode baca good reading, artinya hipotesis: diterima. Disini tampak bahwa dengan menggunakan metode PAP ( Penilaian Acuan Patokan ) derajat kepercayaannya lebih tinggi yakni mencapai 95\% dibandingkan dengan menggunakan modifikasi Sturges. Terlihat bahwa mereka yang memiliki IPK tinggi memiliki capaian prestasi akademik nilai $\mathrm{C}$ dan $\mathrm{D}$, yakni mencapai kisaran $70 \%$ dan nilai $\mathrm{E}$ dan $\mathrm{B}$ mencapai $30 \%$. Hal ini menunjukkan bahwa metode baca good reading masih memerlukan 
keterlatihan penggunanya, jika menghendaki capaian nilai yang optimal. Sementara mereka yang memiliki IPK rendah, cenderung mendapatkan capaian nilai yang rendah, yakni D dan E. Hal ini juga menunjukkan bahwa masih perlu adanya adaptasi penggunaan metode baca, yakni metode baca good reading.

Jika $\alpha=0.01 ; \mathrm{df}=4$, maka Chi-quadrat (tabel) $=13.30$; artinya Chi-quadrat (hitung) = 9.85 lebih kecil daripada Chi-quadrat (tabel) $=13.30$. Jika Chi-quadrat (hitung) lebih kecil daripada Chi-quadrat (tabel), maka prestasi akademik mahasiswa memiliki hubungan nonsignificantdengan metode baca good reading. Kesimpulan: dengan kepercayaan 99\% diketahui bahwa prestasi akademik mahasiswa memiliki hubungan non-significant dengan metode baca good reading, artinya hipotesis: ditolak.

Selanjutnya eksperimen dilakukan pada Kelompok Kontrol dengan $\mathrm{N}=44$, dimana hipotesisnya yakni : $\mathrm{H}_{0}$ : Prestasi akademik memiliki hubungan non-significant dengan kemampuan baca mahasiswa. $\mathrm{H}_{1}$ : Prestasi akademik memiliki hubungan significant dengan kemampuan baca mahasiswa.

Berdasarkan hasil penelitian, maka diperoleh hasil sebagai berikut :

Tabel 3 : Hubungan Prestasi Akademik Mahasiswa Dengan

Metode Baca Reading Habit Berdasarkan Klasifikasi Sturges

\begin{tabular}{|c|c|c|c|c|}
\hline & $\begin{array}{l}\text { Nilai rendah } \\
(17-40)\end{array}$ & $\begin{array}{l}\text { Nilai sedang } \\
(41-64)\end{array}$ & $\begin{array}{l}\text { Nilai tinggi } \\
(65-88)\end{array}$ & Jumlah \\
\hline $\begin{array}{c}\text { IPK tinggi } \\
(3.33-4.00)\end{array}$ & 2 & 12 & 17 & 31 \\
\hline $\begin{array}{c}\text { IPK rendah } \\
(2.64-3.32)\end{array}$ & 3 & 5.61 & 3 & 13 \\
\hline Jumlah & 5 & 19 & 20 & 44 \\
\hline
\end{tabular}

$$
\begin{array}{rlrl}
\mathrm{E}_{11} & =(5 \times 31) / 44=3.52 & \mathrm{E}_{21}=(5 \times 13) / 44=1.47 \\
\mathrm{E}_{12}=(19 \times 31) / 44=13.38 & \mathrm{E}_{22}=(19 \times 13) / 44=5.61 \\
\mathrm{E}_{13}=(20 \times 31) / 44=14.09 & \mathrm{E}_{23}=(20 \times 13) / 44=5.90 \\
2 & =\frac{(2-3.52)^{2}}{3.52}+\frac{(12-13.38)^{2}}{13.38}+\frac{(17-14.09)^{2}}{14.09}+\frac{(3-1.47)^{2}}{1.47}+\frac{(7-5.61)^{2}}{5.61} \\
& +\frac{(3-5.90)^{2}}{5.90} & & \\
& =4.74
\end{array}
$$

Jika $\alpha=0.10 ; \mathrm{df}=2$, maka Chi-quadrat (tabel) $=4.61$; artinya Chi-quadrat (hitung) $=4.74$ lebih besar daripada Chi-quadrat (tabel) $=4$.61. Jika Chi-quadrat (hitung) lebih besar daripada 
Chi-quadrat (tabel), maka hubungan prestasi akademik dengan metode baca reading habit, significant. Kesimpulan: dengan derajat kepercayaan 90\% diketahui bahwa prestasi akademik memiliki hubungan significant dengan metode baca reading habit, artinya hipotesis: diterima. Jika kita cermati berdasarkan banyaknya frekuensi (f) partisipan, mereka yang memiliki IPK tinggi dan rendah kurang lebih (70\%: 30\%), artinya disini mahasiswa dengan IPK tinggi lebih banyak dibandingkan dengan mereka yang IPK rendah. Mereka yang memiliki IPK tinggi memiliki sebaran nilai diantara nilai tinggi - sedang. Sementara mereka yang memiliki IPK rendah memiliki sebaran nilai sedang, dan disini terdapat keseimbangan antar nilai tinggi dan nilai rendah. Mereka sudah adaptif dengan reading habit yang mereka miliki dan cenderung pola berulang, artinya jika biasanya nilai rendah akan cenderung memiliki capaian yang rendah pula. Jika biasanya nilai tinggi akan cenderung memiliki capaian yang tinggi. Namun bagi mereka yang memiliki IPK rendah akan memiliki kecenderungan yang beresiko, yakni bisa tinggi atau rendah.

Jika $\alpha=0.05 ; \mathrm{df}=2$, maka Chi-quadrat (tabel) $=5.99$; artinya Chi-quadrat (hitung) $=4.74$ lebih kecil daripada Chi-quadrat (tabel) $=5.99$. Jika Chi-quadrat (hitung) lebih kecil daripada Chi-quadrat (tabel), maka hubungan prestasi akademik dengan metode baca reading habit, nonsignificant. Kesimpulan: dengan derajat kepercayaan 95\% diketahui bahwa prestasi akademik memiliki hubungan non-significant dengan metode baca reading habit, artinya hipotesis: ditolak.

Selanjutnya, jika kita coba lakukan rekayasa konseptual nilai mutu akademik, yakni penilaian penguasaan materi secara kognitif, psikomotorik, dan afeksi dengan menggunakan PAP (Penilaian Acuan Patokan) sebagai berikut : A (80 - 100), B (68 - 79), C (56 - 67), D (45 - 55), $\mathrm{E}(0-44)$.

Tabel 4 : Hubungan Prestasi Akademik Mahasiswa Dengan Metode Baca Reading Habit Berdasarkan Klasifikasi PAP

\begin{tabular}{|c|c|c|c|c|c|c|}
\hline & $\begin{array}{c}E \\
(0-44)\end{array}$ & $\begin{array}{c}\mathrm{D} \\
(44-55)\end{array}$ & $\begin{array}{c}\mathrm{C} \\
(56-67)\end{array}$ & $\begin{array}{c}\mathrm{B} \\
(68-79)\end{array}$ & $\begin{array}{c}\mathrm{A} \\
(80-100)\end{array}$ & Jumlah \\
\hline $\begin{array}{c}\text { IPK tinggi } \\
(3.33-4.00) \\
\end{array}$ & $\begin{array}{ll}2 & \\
& 2.82\end{array}$ & 5 & $\begin{array}{ll}17 & \\
& 16.90\end{array}$ & 4.23 & 1.41 & 31 \\
\hline $\begin{array}{l}\text { IPK rendah } \\
(2.64-3.32)\end{array}$ & $\begin{array}{ll}2 & \\
& 1.18\end{array}$ & 3 & 7.09 & 1.77 & 0.59 & 13 \\
\hline Jumlah & 4 & 8 & 24 & 6 & 2 & 44 \\
\hline
\end{tabular}

$$
\begin{array}{ll}
\mathrm{E}_{11}=(4 \times 31) / 44=2.82 & \mathrm{E}_{21}=(4 \times 13) / 44=1.18 \\
\mathrm{E}_{12}=(8 \times 31) / 44=5.64 & \mathrm{E}_{22}=(8 \times 13) / 44=2.36 \\
\mathrm{E}_{13}=(24 \times 31) / 44=16.90 & \mathrm{E}_{23}=(24 \times 13) / 44=7.09
\end{array}
$$




$$
\begin{aligned}
\mathrm{E}_{14}= & \left(\begin{array}{ll}
6 \times 31) / 44=4.23 & \mathrm{E}_{24}=(6 \times 13) / 44=1.77 \\
\mathrm{E}_{15}= & (2 \times 31) / 44=1.41
\end{array} \mathrm{E}_{25}=(2 \times 13) / 44=0.59\right. \\
{ }^{2}= & \frac{(2-2.82)^{2}}{2.82}+\frac{(5-5.64)^{2}}{5.64}+\frac{(17-16.90)^{2}}{16.90}+\frac{(5-4.23)^{2}}{4.23}+\frac{(2-1.41)^{2}}{1.41} \\
& \frac{(2-1.18)^{2}}{1.18}+\frac{(3-2.36)^{2}}{2.36}+\frac{(7-7.09)^{2}}{7.09}+\frac{(1-1.77)^{2}}{1.77}+\frac{(0-0.59)^{2}}{0.59} \\
= & 2.05
\end{aligned}
$$

Jika $\alpha=0.10 ; \mathrm{df}=4$, maka Chi-quadrat (tabel) $=7.78$; artinya Chi-quadrat (hitung) = 2.05 lebih kecil daripada Chi-quadrat (tabel) $=7.78$. Jika Chi-quadrat (hitung) lebih kecil daripada Chi-quadrat (tabel), maka hubungan prestasi akademik dengan kemampuan baca mahasiswa, non-significant. Kesimpulan: dengan derajat kepercayaan 90\% diketahui bahwa prestasi akademik memiliki hubungan non-significant dengan metode baca reading habit, artinya hipotesis: ditolak. Disini cukup beresiko, jika kita turunkan derajat kepercayaannya dibawah 90\%, artinya akan semakin kurang dipercaya.

Metode PAP (Penilaian Acuan Patokan) tampak memiliki pengaruh pada capaian prestasi akademik mahasiswa, arinya disini tidak lagi mengacu pada capaian kemampuan prestasi kelas, melainkan menggunakan patokan (PAP). Disini IPK mahasiswa tidak memiliki keterkaitan dengan capaian prestasi akademik. Kebiasaan baca yang mereka miliki (reading habit) tidak dapat diandalkan sebagai metode baca yang mampu mendongkrak capaian prestasi akademiknya. Mereka yang memiliki IPK tinggi memiliki kecenderungan memperoleh capaian prestasi akademik nilai sedang. Sementara untuk capaian nilai tinggi dan nilai rendah cenderung seimbang. Mereka yang memiliki IPK rendah memiliki kecenderungan memperoleh capaian prestasi akademik nilai sedang ke rendah, dan cukup sulit memiliki capaian nilai tinggi.

\section{Kesimpulan}

Berdasarkan hasil penelitian menggunakan metode eksperimen diatas, maka kesimpulan penelitian ini adalah:

a. Jika prestasi akademik diklasifikasi menurut klasifikasi Sturges (modifikasi) dengan derajat kepercayaan 90\%, maka prestasi akademik mahasiswa memiliki hubungan significant dengan metode baca good reading.

b. Jika prestasi akademik diklasifikasi menurut klasifikasi PAP (Penilaian Acuan Patokan) dengan derajat kepercayaan 95\%, maka prestasi akademik memiliki hubungan significant dengan metode baca good reading. 
c. Metode baca good reading lebih dipercaya jika capaian prestasi akademik menggunakan metode penilaian PAP.

d. Metode baca good reading memerlukan adaptasi dalam penggunaannya, semakin sering menggunakan metode baca good reading, makin memiliki peluang yang meningkat pada capaian prestasi akademiknya.

e. Metode baca good reading memerlukan keterlatihan, semakin terlatih menggunakan metode baca good reading, makin cepat waktu bacanya dan memiliki capaian prestasi akademik yang optimal. Mereka yang memiliki IPK tinggi akan memiliki capaian prestasi akademik yang tinggi, jika menggunakan metode baca good reading. Demikian juga bagi mereka yang memiliki IPK rendah akan memiliki capaian prestasi akademik yang cenderung menuju tinggi, artinya akan mampu mendongkrak capaian prestasi akademik.

f. Metode baca memiliki keterkaitan dengan capaian prestasi akademik mahasiswa. Metode baca good reading dapat dijadikan solusi alternatif dalam mendongkrak prestasi akademik mahasiswa.

\section{Referensi}

Adler, M. J. \& Doren, C. V. 1972. How to Read a Book. American edition.

Babbie, E. 1986. The Practice of Social Research. California : Wadsworth Publishing, fourth edition.

Babbie, E. 2008. The Basics of Social Research. Fourth edition. International student edition.

Fisher, K. E. 2008. Theories of Information Behavior. New Delhi : Ess Publication.

Hatt, F. 1986. The Reading Process a Framwork for Analysis and Description. London : Clive Bingley.

Krathwohl, D. R. 1993. Methods of Educational and Social Science. New York : Longman.

Prijana, Asep Saeful Rohman. 2015. Kemampuan Baca Mahasiswa Pada Buku Teks. Laporan Penelitian : DRPM Unpad

Prijana. 2016. Hubungan Membaca Teks Ilmu Pengetahuan Melalui Metode Good Reading Dengan Nilai Prestasi Akademik. Bandung: Artikel Prosiding International Converence. Fikom Unpad.

Prijana, Winoto, Y., Andriyanto. 2016. Metode Penelitian Kuantitatif. Bandung : Unpad Press.

Prijana, Wina, R. W., Winoto, Y. 2016. Model dan Teori Ilmu Perpustakaan Dan Informasi. Bandung : Unpad Press.

Prijana. 2005. Metode Sampling Terapan. Bandung : Humaniora.

Prijana \& Andri Yanto. 2016. Uji Korelasi Tentang Prestasi Akademik Dengan Metode Baca Mahasiswa. Artikel Prosiding Seminar Nasional. Lampung : Unila. 
Prijana \& Sukaesih. 2016. Hubungan Kemampuan Baca Mahasiswa Melalui Metode Good Reading Dengan Kemampuan Menjawab Soal Multiplechoice. Artikel Jurnal Edulib Edisi November 2016. Bandung : UPI

Sevilla, C. G. 2008. Pengantar Metode Penelitian. Jakarta : UI Press.

Singarimbun, M. \& Effendi, S. 1989. Metode Penelitian Survai. Jakarta : LP3ES.

Sudjana. 2005. Metoda Statistika. Bandung : Transito.

Sukaesih. 2007. Kemampuan Membaca Dalam Konteks Information Literacy. Makalah. Bandung : Unpad 